\title{
UPAYA MENINGKATKAN NASABAH TABUNGAN MELALUI TABUNGAN BAJAPUIK PADA PT. BANK PERKREDITAN RAKYAT (BPR) JORONG KAMPUANG TANGAH (JKT) PARIAMAN
}

\author{
Adnan Habibulil Amri, Ratna Widayati \\ Akademi Keuangan dan Perbankan Padang \\ ratnawidayati@akbpstie.ac.id
}

\begin{abstract}
Many ways the Rural Bank to increase the number of customers by increasing the interest rate savings, eliminating administrative costs to pick up savings. This is believed to increase the number of customers in Rural Banks. Savings transfer is a special service given to its customers, with the aim of facilitating customers to save. With savings pickup, customers do not have to come directly to the bank to save. Efforts to increase customers through savings in PT.BPR JKT Pariaman is Relying on traditional marketing patterns that is by using the system pick up the ball by using Bajapuik Savings service. Bajapuik savings that get a positive response from customers make savings bajapuik become very popular among customers.
\end{abstract}

Keyword: customers by increasing, Bajapuik savings

\section{PENDAHULUAN}

Menurut UU No. 10 Tahun 1998 Tentang perubahan atas UU No. 7 Tahun 1992 tentang perbankan Pasal 1(2): "Bank adalah badan usaha yang menghimpun dana dari masyarakat dalam bentuk simpanan dan menyalurkan kepada masyarakat dalam bentuk kredit dan atau bentuk-bentuk lainnya dalam rangka meningkatkan taraf hidup rakyat banyak".

Perkembangan bank sangat pesat yang merupakan dampak dari pertumbuhan ekonomi masyarakat sehingga terjadi persaingan yang sangat ketat dalam dunia perbankan. Berbagai produk bank dikeluarkan dengan berbagai fasilitas dan kemudahan bertujuan menarik minat masyarakat untuk menggunakan jasa bank tersebut. Masyarakat dalam menentukan jasa perbankan sesuai dengan kebutuhan, sekarang ini semakin banyak masyarakat yang memahami manfaat atau fungsi bank untuk melakukan penyimpanan atau 
melakukan transaksi keuangan sehingga masyarakat akan memilih bank secara lebih selektif.

Seiring dengan perkembangan perbankan, banyak bank mulai bermunculan, salah satunya Bank Perkreditan Rakyat (BPR). Bank Perkreditan Rakyat adalah lembaga keuangan bank yang menerima simpanan hanya dalam bentuk deposito berjangka, tabungan, danatau bentuk lainnya yang dipersamakan dan menyalurkan dana sebagai usaha BPR.

Menurut pasal 13 Undang-Undang Nomor 10 Tahun 1998, BPR mempunyai tugas sebagai berikut :menghimpun dana dari masyarakat dalam bentuk simpanan berupa deposito berjagka, tabungan, dan atau bentuk lain yang dipersamakan dengan itu, memberikan kredit kepada masyarakat dan menyediakan pembiayaan bagi nasabah berdasarkan prinsip bagi hasil.

Berdasarkan uraian di atas, maka penulis berinisiatif melakukan penelitian dan membahasnya dalam penelitian yang berjudul "Upaya Meningkatkan Jumlah Nasabah Tabungan Melalui Tabungan Bajapuik Pada Kantor Pusat PT. Bank Perkreditan Rakyat Jorong Kampuang Tangah (JKT) Pariaman".

Setelah mempelajari latar belakang masalah diatas, maka rumusan masalah yang diambil sebagai kajian dalam penelitian yang akan dilakukan ini adalah bagaimana upaya meningkatkan nasabah tabungan pada kantorpusat PT Bank Perkreditan Rakyat Jorong Kampuang Tangah Pariaman

Untuk keperluan penelitian ini, pengumpulan data dilakukan dengan dua cara yaitu penelitian: 1) Riset Perpustakaan (Library Research), yaitu pengumpulan data dengan cara mempelajari teori-teori dari literatur dan bukubuku yang ada kaitannya dengan objek penelitian. 2) Riset Lapangan (Field Research), yaitu melakukan penelitian langsung untuk mendapatkan data primer dan data sekunder.

Dalam menganalisa data, penulis menggunakan metode analisa data kualitatif sebagai metode penelitian yang menjelaskan secara deskriptif mengenai mekanis meningkatkan nasabah Tabungan pada PT. Bank Perkreditan Rakyat Jorong Kampuang Tangah. Metode analisa ditinjau dari dua segi yang berbeda yaitu antara teori dan praktek sehingga dapat diketahui sejauh mana pelaksanaannya, apakah perbedaan yang timbul menyangkut prinsip dasar konsep itu sendiri. Dengan menganalisa perbandingan, pertanyaan itu akan terjawab selanjutnya dan hasil analisa itu dipergunakan sebagai dasar pengambilan kesimpulan dan saran.

Tujuan dari penulisan tugas akhir ini adalah untuk mengetahui dan memahami bagaimana upaya meningkatkan nasabah tabungan pada kantor 
pusat PT Bank Perkreditan Rakyat Jorong Kampuang Tangah (JKT) Pariaman adalah sebagai berikut : Bagi Penulis, merupakan alat untuk mengembangkan ilmu pengetahuan yang telah didapatkan selama berada di bangku perkuliahan dan untuk memperluas pengetahuan.Bagi Kantor Pusat Bank Perkreditan Rakyat Jorong Kampuang Tangah, penelitian ini diharapkan dapat bermanfaat sebagai bahan masukan, khususnya dalam pengembangan tabungan bajapuik.Bagi Instansi Pendidikan, diharapkan dapat dijadikan sebagai pedoman dan informasi bagi penelitian berikutnya yang berkaitan dengan meningkatkan jumlah nasabah pada Bank Perkreditan Rakyat.

\section{ANALISA DAN PEMBAHASAN}

\section{Pengertian Bank}

Menurut Kasmir, mendefinisikan bank sebagai berikut:"Bank merupakan lembaga keuangan yang memberikan jasa keuangan yang paling lengkap, disamping menyalurkan dana atau memberikan pinjaman (kredit) juga melakukan usaha menghimpun dana dari masyarakat luas dalam bentuk simpanan, serta memberikan jasa-jasa keuangan lainnya yang mendukung dan memperlancar kegiatan memberi pinjaman dengan kegiatan menghimpun dana".(Ii, n.d.)

Menurut UU No. 10 Tahun 1998“Bank adalah badan usaha yang menghimpun dana dari masyarakat dalam bentuk simpanan dan menyalurkannya ke masyarakat dalam bentuk kredit dan atau bentukbentuk lainnya dalam rangka meningkatkan taraf hidup rakyat banyak."

\section{Pengertian BPR}

Bank Perkreditan Rakyat adalah bank yang melaksanakan kegiatan usaha secara konvesional atau berdasarkan prinsip syariah yang dalam kenyataannya tidak memberikan jasa dalam lalu lintas pembayaran. Dengan lokasi yang pada umumnya dekat dengan tempat masyarakat yang membutuhkan.(Ii \& Bpr, 1992)

Status BPR ini diberikan kepada Bank Desa, Lumbung Desa, Bank Pasar, Bank Pegawai, Lumbung Pitih Nagari (LPN), Lembaga Perkreditan Desa (LPD), Badan Kredit Desa (BKD), Badan Kredit Kecamatan (BKK), Kredit Usaha Rakyat Kecil (KURK), Lembaga Perkreditan Kecamatan (LPK), Bank Karya Produksi Desa (BKPD), dan/atau lembaga-lembaga lainnya yang dipersamakan berdasarkan UU Perbankan Nomor 10 Tahun 1998 dengan memenuhi suatu persyaratan tatacara yang ditetapkan dengan suatu Peraturan Pemerintah. 
Ketentuan tersebut diberlakukan karena mengingat bahwa lembagalembaga tersebut sudah berkembang dari lingkungan masyarakat Indonesia, serta masih diperlukan oleh masyarakat, maka keberadaan lembaga dimaksud diakui. Oleh sebab itu, UU Perbankan Nomor 10 Tahun 1998 memberikan suatu kejelasan status lembaga-lembaga yang dimaksud. Untuk menjamin kesatuan dan keseragaman dalam suatu pembinaan dan pengawasan, maka persyratan dan tatacara pemberian status lembaga-lembaga yang dimaksud ditetapkan dengan Peraturan Pemerintah.

Tugas Bank Perkreditan Rakyatmenurut pasal 13 UU Perbankan No. 10 tahun 1998, Bank Perkreditan Rakyat mempunyai suatu kegiatan usaha yaitu sebagai berikut: 1) bertugas untuk menghimpun dana dari masyarakat dalam bentuk simpanan yang berupa deposito berjangka, tabungan, dan/atau bentuk lainnya yang dipersamakan dengan itu. 2) bertugas memberikan kredit. 3) bertugasuntuk menyediakan pembiayaan dan penempatan dana berdasarkan prinsip syariah, sesuai dengan ketentuan yang ditetapkan oleh Bank Indonesia. 4) bertugasuntuk menempatkan dananya dalam bentuk Sertifikat Bank Indonesia (SBI), deposito berjangka, sertifikat deposito, dan/atau tabungan pada bank lain.

Fungsi Bank perkreditan Rakyat yaitu : 1) berfungsi untuk memberikan suatu pelayanan kepada masyarakat untuk menerima tabungan mereka dalam bentuk deposito berjangka, tabungan, dan/atau bentuk lainnya yang dipersamakan dengan itu; 2) berfungsi untuk memberikan kredit; 3) berfungsi untuk menyediakan pembiayaan bagi nasabah yang berdasarkan prinsip bagi hasil sesuai dengan ketentuan yang ditetapkan dalam peraturan pemerintah; serta 4) berfungsi untuk menempatkan dananya dalam bentuk Sertifikat Bank Indonesia (SBI), deposito berjangka, sertifikat deposito, dan atau pada bank lain.(Ii \& Bpr, 1992).

\section{Pengertian Tabungan}

Tabungan merupakan jenis simpanan yang dilakukan oleh pihak ketiga yang penarikannya dapat dilakukan menurut syarat tertentu sesuai perjanjian antara bank dan pihak nasabah.(Ii \& Tabungan, 2008)

Tabungan merupakan simpanan yang paling populer dikalanganmasyarakat umum lain dari masyarakat kota sampai pedesaan. MenurutUndang-Undang Perbankan No.10 Tahun 1998 pasal 1(9), Tabungan adalahsimpanan yang penarikannya hanya dapat dilakukan menurut syarattertentu yang disepakati, tetapi tidak dapat ditarik dengan cek, bilyet giro,atau alat lainnya yang dipersamakan dengan itu. 
Persyaratan untuk dapat membuka rekening tabungan, masing-masing bank berbeda. Akan tetapi, pada umumnya bank memberikan persyaratan yang sama pada setiap bank yaitu setiap masyarakat yang ingin membuka rekening tabungan, perlu menyerahkan fotocopy identitas, misalnya KTP, SIM, paspor, dan identitas lainnya. Setiap bank akan memberikan persyaratan tentang setoran awal, minimal, serta saldo minimal yang harus disisakan. Saldo minimal diperlukan apabila tabungan akan ditutup, maka terdapat saldo yang akan digunakan untuk membayar biaya administrasi penutupan tabungan. (Ii \& Tabungan, 2008)

Sarana Penarikan Tabungan Untuk menarik dana yang ada direkening tabungan dapat digunakan berbagai sarana atau alat penarikan. Ada beberapa penarikan yang dapat digunakan, hal ini tergantung bank masing-masing, mau menggunakan sarana yang mereka inginkan. Alat-alat yang sering digunakan sebagai berikut: 1) Buku Tabungan, buku tabungan merupakan salah satu bukti bahwa nasabah tersebut adalah nasabah penabung di bank tertentu. Setiap nasabah tabungan akan diberikan buku tabungan, yaitu merupakan buku yang menggambarkan mutasi setoran, penarikan, dan saldo atas setiap transaksi yang terjadi, sehingga langsung dapat mengurangi atau menambah saldo yang ada dibuku tabungan tersebut. 2) Slip Penarikan, merupakan formulir untuk menarik sejumlah uang dari rekening tabungannya. Di dalam formulir penarikan nasabah cukup menulis nama, nomor rekening, jumlah uang, serta tanda tangan nasabah. Formulir penarikan ini disebut juga slip penarikan dan biasanya digunakan bersamaan dengan buku tabungan. 3) Kwitansi, kwitansi juga merupakan formulir penarikan dan juga merupakan bukti penarikan yang dikeluarkan oleh bank yang fungsinya sama dengan slip penarikan. Di dalam kwitansi tertulis nama penarik, nomor penarik, jumlah uang, dan tanda tangan penarik. Alat ini juga dapat digunakan secara bersamaan dengan buku tabungan.(Ii \& Tabungan, 2008).

\section{Promotion (Promosi)}

Promosi adalah berbagai kegiatan yang dilakukan olehperusahaan untuk menonjolkan keistimewaan produknya dan membujuk konsumen sasaran agar membeli produknya.Tiga alat promosi yang penting adalah iklan, promosi penjualan dan publisitas. Ketigannya adalah alat-alat pemasaran missal kebalikan dari penjualan personal yang membidik sasaran para pembeli khusus(Ii, n.d.)

\section{Periklanan (Advertsing)}

Iklan adalah sarana promosi yang digunakan oleh bank guna menginformasikan, segala sesuatu produk yang dihasilkan oleh bank.Informasi 
yang diberikan adalah manfaat produk, harga produk serta keuntungankeuntungan produk dibandingkan pesaing.Tujuan promosi lewat iklan adalah berusaha untuk menarik, dan mempengaruhi calon nasabahnya.

Penggunaan promosi dengan iklan dapat dilakukan dengan berbagai media, seperti lewat: a) pemasangan billboard (papan nama) di jalan-jalan strategis. b) Pencetakan brosur baik disebarkan di setiap cabang atau pusatpusat perbelanjaan. c) pemasanganspanduk di lokasi tertentu yang strategis. d) melaluiKoran. e) Melalui Majalah. f) Melalui Televisi.g) Melalui Radiodan menggunakan media lainnya.

\section{Promosi Penjualan (Sales Promotion)}

Di samping promosi lewat iklan, promosi lainnya dapat dilakukan melalui promosi penjualan atau sales promotion.Tujuan promosi penjualan adalah untuk meningkatkan penjualan atau untuk meningkatkan jumlah nasabah.Promosi penjualan dilakukan untuk menarik nasabah untuk segera membeli setiap produk atau jasa yang ditawarkan.Tentu saja agar nasabah tertarik untuk membeli, maka perlu dibuatkan promosi penjualan yang semenarik mungkin.

Promosi penjualan dapat dilakukan melalui pemberian diskon, kontes, kupon atau sample produk. Dengan menggunakan alat tersebut akan memberikan 3 manfaat bagi promosi penjualan, yaitu : a) komunikasi, yaitu memberikan informasi yang dapat menarik perhatian nasabah untuk membeli. b) Insentif, yaitu memberikan dorongan dan semangat kepada nasabah untuk segera membeli produk yang ditawarkan. c) Invitasi mengharapkan nasabah segera merealisasi pembelian.

Bagi bank promosi penjualan dapat dilakukan melalui : a) Pemberian bunga khusus untuk jumlah dana yang relative besar walaupun hal ini akan mengakibatkan persaingan tidak sehat. b) Pemberian insentif kepada setiap nasabah yang memiliki simpanan dengan saldo tertentu. c) Pemberian cinderamata, hadiah serta kenang-kenangan lainnya kepada nasabah yang loyaldan promosi penjualan lainnya.

Sama seperti halnya dengan iklan, promosi penjualan juga memiliki program tersendiri. Dalam praktiknya program promosi penjualan memiliki tiga macam cara, yaitu : a) Promosi Konsumen, seperti penggunaan kupon, sample produk, atau bentuk undian.b) Promosi Dagang yaitu berupa bantuan peralatan atau insentif. c) Promosi Wiraniaga, melalui kontes penjualan.(Ii, n.d.) 


\section{PEMBAHASAN}

PT. BPR JKT adalah bank yang melaksanakan kegiatan usaha secara konvensional yang dalam kegiatanya adalah menghimpun dana dalam bentuk tabungan, deposito dan menyalurkannya dalam bentuk kredit / pembiayaan. Dengan lokasi yang pada umumnya dekat dengan tempat masyarakat yang membutuhkan.

Status PT. BPR JKT Pariaman merupakan Bank Desa, Lumbung Desa, Bank Pasar, Bank Pegawai, Lumbung Pitih Nagari (LPN), Lembaga Perkreditan Desa (LPD), Badan Kredit Desa (BKD), Badan Kredit Kecamatan (BKK), Kredit Usaha Rakyat Kecil (KURK), Lembaga Perkreditan Kecamatan (LPK), Bank Karya Produksi Desa (BKPD), dan/atau lembaga-lembaga lainnya yang dipersamakan dengan itu.

\section{Kegiatan Usaha}

Kegiatan operasional PT. Bank Perkreditan Rakyat JKT - Pariaman adalah menghimpun dana dalam bentuk tabungan dan deposito, serta menyalurkan dana dalam bentuk kredit.

Tabungan yang ada pada PT. BPR JKT antaralain : 1) TAMASDA (Tabungan Masyarakat Daerah), merupakan singkatan dari Tabungan Masyarakat Daerah. Tabungan yang diperuntukkan untuk masyarakat luas, yang berdomisili di kota pariaman, tetapi tidak diperuntukkan untuk pelajar. 2) TAN (Tabungan Anak Nagari), merupakan singkatan dari Tabungan Anak Nagari. Tabungan yang digunakan bagi masyarakat luas, yang tidak berdomisili di kota pariaman, tetapi tidak diperuntukkan untuk para pelajar. 3) TABSIS (Tabungan Siswa), merupakan singkatan dari Tabungan Siswa.Tabungan yang diperuntukkan untuk para pelajar yang masih duduk dibangku sekolah.

Sarana Penarikan Tabungan Untuk menarik dana yang ada direkening tabungan dapat digunakan berbagai sarana atau alat penarikan. Ada beberapa penarikan yang dapat digunakan, hal ini tergantung bank masing-masing, mau menggunakan sarana yang mereka inginkan. Alat-alat yang sering digunakan sebagai berikut : 1) Buku Tabungan, merupakan salah satu bukti bahwa nasabah tersebut adalah nasabah penabung di bank tertentu. Setiap nasabah tabungan akan diberikan buku tabungan, yaitu merupakan buku yang menggambarkan mutasi setoran, penarikan, dan saldo atas setiap transaksi yang terjadi, sehingga langsung dapat mengurangi atau menambah saldo yang ada dibuku tabungan tersebut. 2) Slip Penarikan, merupakan formulir untuk menarik sejumlah uang dari rekening tabungannya. Di dalam formulir penarikan nasabah cukup menulis nama, nomor rekening, jumlah uang, serta 
tanda tangan nasabah. Formulir penarikan ini disebut juga slip penarikan dan biasanya digunakan bersamaan dengan buku tabungan.

Selain menghimpun dana dari Tabungan, PT BPR juga menghimpun dana melalui deposito berjangka. Deposito yang ada pada PT. BPR JKT antara lain : 1) Jangka Waktu 1 Bulan. 2) Jangka Waktu 3 Bulan. 3) Jangka waktu 6 Bulan. 4) Jangka Waktu 12 Bulan.

Untuk menyalurkan dananya PT. BPR JKT juga memberikan kredit dan juga pembiayaan. Kredit dan pembiayaan yang ada pada PT. BPR JKT Pariaman adalah : 1) KreditInstalmentadalah kredit yang pembayaran pokok dan bunganya dilakukan secara berkala dalam jumlah angsuran yang sama pada jangka waktu tertentu.2) KreditReguleradalah kredit yang pembayaran pokok dan bunga dibayar terpisah, dimana pembayaran bunganya dibayar terlebih dahulu setiap bulan, sementara angsuran pokoknya dibayar setelah jatuh tempo pembayarannya. 3) Kredit Lembaga Pembiayaan Dana Bergulir (LPDB)adalah kredit yang pembayaran pokok dan bunga secara berkala dengan tingkat suku bunga yang rendah dan dananya diberikan oleh pemerintah.

\section{Upaya Meningkatkan Nasabah Tabungan}

Untuk meningkatkan nasabah tabungan , PT. BPR JKT melakukan berbagai cara di antaranya : 1) Menyebarkan brosur, PT. BPR JKT menyebarkan brosur kepada calon nasabah yang ingin menabung di PT. BPR JKT. Supaya calon nasabah mengetahui produk dan jasa yang adapada PT. BPR JKT. 2) Membagikan Kalender, PT. BPR JKT memberikan kalender kepada nasabah/ calon nasabah yang berisikan foto kegiatan PT. BPR JKT itu sendiri, Produk/Jasa yang ada pada PT. BPR-JKT. Kalender ini di bagian langsung oleh karyawan PT.BPR JKT kerumah nasabah/Calon nasabah.3) Membagikan Parcel, pembagian Parcel/bingkisan biasanya dibagikan sebelum hari hari besar kepada nasabah setia PT. BPR JKT agar tetap setia menjadi nasabah PT. BPR JKT. Parcel yang dibagikan biasanya berisi Sembako/makanan ringan yang dapat dipergunakan nasabah pada saat hari besar nanti. 4) Mengadakan acara tahunan, acara tahunan yang di maksud disini adalah untuk menyambut ulang tahun PT.BPR JKT Pariaman. Acara yang diselenggarakan setiap tahunnya dengan membagikan hadiah kepada nasabah yang beruntung. Acara tersebut di adakan di kantor pusat PT. BPR JKT Pariaman yakni di Jl. Merdeka No 18 Kelurahan Kampung Perak, Kecamatan Pariaman Tengah, Kota Pariaman. Nasabah di undang untuk menghadir iacara tersebut untuk menyaksikan langsung pengundian hadiah berdasarkan nomor rekening nasabah. 


\section{Tabungan Bajapuik}

Merupakan layanan yang di berikan PT. BPR JKT kepadanasabahnya, dengan tujuan memudahkan nasabah untuk menabung. Nasabah tidak harus pergi ke PT. BPR JKT Pariaman untuk menabung. Selain Menjemput tabungan nasabah juga dapat melakukan penarikan, dengan syarat harus membertahu terlebih dahulu sebelum melakukan penarikan, agar dananasabah dapat di disediakan pada saatpenjemputan tabungan atau hanya sekedar melakukan penarikan.

Tabungan Bajapuik adalah proses penjemputan tabungan yang dilakukan secara kolektif kealamat / ketempat usaha nasabah itu sendiri. Di jemput atas kemauan nasabah, bias setiap hari ataupun sekali seminggu, tergantung kepada nasabah itu sendiri. Nasabah harus mengkonfirmasi pada saat pembuatan rekening, mau di jemput dimana dan di jemput sekali berapa hari. Tabungan yang biasa dijemput adalah tabungan jenis Tabungan Anak Nagari (TAN), Tabungan Masayarakat daerah (TAMASDA), dan ada beberapa Tabungan siswa (TABSIS).

Dari upaya yang di lakukan PT. BPR JKT Pariaman dan pelayanan tabungan bajapuik, terjadi peningkatan jumlah nasabah yang dapat dilihat dari tabel berikut :

\section{Tabel 1}

Jumlah Nasabah Tabungan PT.BPR Jorong Kampuang Tangah

Pariaman 2013-2017

\begin{tabular}{|c|c|c|c|c|c|}
\hline Tahun & $\mathbf{2 0 1 3}$ & $\mathbf{2 0 1 4}$ & $\mathbf{2 0 1 5}$ & $\mathbf{2 0 1 6}$ & $\mathbf{2 0 1 7}$ \\
\hline Jumlah Nasabah & 10.734 & 11.756 & 12.825 & 14.406 & 15.036 \\
\hline
\end{tabular}

Sumber : PT.BPR JKT Pariaman

Tabel di atas, menunjukan peningkatan nasabah dari tahun ketahun.Pada tahun2013- 2014 peningkatan jumlah nasabah sebanyak 1022 nasabah, pada tahun 2014- 2015 meningkat sebanyak 1069 nasabah,2015- 2016 meningkat sebanyak 1581 nasabah, dan pada tahun 2016- 2017 meningkat 630 nasabah.Peningkatan nasabah paling banyak terjadi pada tahun2015- 2016 yaitu sebanyak 1561, dan yang paling sedikit tahun 2016-2017 hanya sebanyak 630.

Peningkatan tersebut terjadi karena upaya yang dilakukan PT.BPR JKT Pariaman untuk meningkatkan nasabah. Serta pelayanan tabungan bajapuik yang mendapatkan respon positif dari nasabah yang menabung.Sebagian besar nasabah merupakan pedagang dan pengusa UMKM. Pedagan dan pengusaha UMKM yang kesehariannya sibuk sangat terbantu akan tabungan bajapuik, sehingga terjadi peningkatkan jumlah nasabah tabungan yang cukup derastis setiap tahunya.

\section{SIMPULAN}

Upayapeningkatan nasabah melalui Tabungan pada PT.BPR JKT Pariaman adalah Mengandalkan pola pemasaran tradisional yaitu dengan menggunakan sistem jemput bola dengan menggunakan layanan Tabungan 
Bajapuik. Tabungan bajapuik yang mendapatkan respon positif dari nasabah membuat tabungan bajapuik menjadi sangat populer di kalangan nasabah. Selain itu PT. BPR JKT juga melakukan upaya lain seperti :

1. Melakukan promosi dengan cara menyebarkan brosur kepada calon nasabah, dengan tujuan agar calon nasabah mengetahui produk dan pelayanan yang ada pada PT. BPR JKT Pariaman.

2. Sedangkan untuk mempertahankan loyalitas nasabah, PT. BPR JKT Pariaman melakukan kegiatan berupa membagikan parcel, dan mengadakan acara tahunan.

\section{UCAPAN TERIMAKASIH}

Alhamdulillahirabbil'alamin, segala puji bagi Allah SWT pencipta seluruh alam semesta yang telah memberikan rahmat dan hidayah-Nya, sehingga penulis mampu menyelesaikan penelitian yang berjudul "Upaya Meningkatkan Jumlah Nasabah Tabungan Melalui Tabungan Bajapuik pada PT. BPR Jorong Kampuang Tangah (JKT)" Penulis juga menyadari bahwa selama berlangsungnya penelitian, penyusunan sampai pada tahap penyelesaian tugas akhir ini tak lepas dari dukungan serta bantuan berbagai pihak. Oleh karena itu teriring do'a dan ucapan terimakasih penulis sampaikan kepada: 1) Kedua orang tua serta saudara-saudaraku tercinta yang telah memberikan nasihat, do'a, dan dukungan moril maupun materil untuk penulis dalam menuntut ilmu, sehingga penyusunan tugas akhir ini dapat terselesaikan. 2) Ibu Afriyeni, SE. MM selaku direktur akademi keuangan dan perbankan "Pembangunan" Padang. 3) Bapak Doni Marlius, SE. MM selaku ketua prodi Akademi Keuangan dan Perbankan "Pembangunan". 4) $\mathrm{Hj}$. Ratna Widayati, $\mathrm{SH}$. MH selaku dosen pembimbing yang telah membimbing penulis dalam menyelesaikan tugas akhir ini. 5) Segenap dosen Jurusan Keuangan dan Perbankan atas segala ilmu dan bimbingannya. 6) Teman-teman angkatan 2015 yang telah saling memotivasi dan membantu terselesainya tugas akhir ini. 7) Seluruh pihak yang tidak bisa penulis sebutkan satu persatu.

\section{DAFTAR PUSTAKA}

Fernandes, Y. D., \& Marlius, D. (2018). Peranan Customer Service Dalam Meningkatkan Pelayanan Kepada Nasabah Pada PT. Bank Pembangunan Daerah Sumatera Barat Cabang Utama Padang. https://doi.org/10.31227/osf.io/wrh3p

Hidayati, R. R., \& Marlius, D. (2018). Aktivitas Promosi Dalam Meningkatkan Dana Pihak Ketiga Pada PT. Bank Perkreditan Rakyat (BPR) Batang Kapas Pesisir Selatan. https://doi.org/10.31227/osf.io/8dgqn

Kasmir, "Pemasaran Bank”, (Jakarta: Kencana,2008), h. 88 Ibid ., h.120 12, 
$12-27$.

Indriyo Gitosudarmo, Manajemen Strategi, Yogyakarta: BPFE, 2001.

Marlius, D. (2016). Pengaruh Bauran Pemasaran Jasa Terhadap Minat Nasabah Dalam Menabung Pada Bank Nagari Cabang Muaralabuh. https://doi.org/10.31227/osf.io/vdqgx

Meidisa, C., \& Susanti, F. (2019). Pengaruh Preferensi Dan Pengetahuan Produk Terhadap Minat Menabung Masyarakat Pada Bank Nagari Unit Layanan Syariah Cabang Pasar Raya Padang. https://doi.org/10.31227/osf.io/bf7cr

Mirawati \& Fernos, J. (2019). Peranan Customer Service Dalam Meningkatkan Pelayanan Terhadap Nasabah Pada Bank Nagari Cabang Siteba Padang. https://doi.org/10.31227/osf.io/cq458

Murti Sumarni, Managemen Pemasaran Bank, Yogyakarta: Liberty Yogyakarta, 2002.

Djumhana, Muhamad, Drs. SH., 2000, Hukum Perbankan di Indonesia, Bandun g: $\quad$ PT. Citra Aditya Bakti

Kasmir, 2000, Bank dan Lembaga Keunagan Lainya, Jakarta : PT. RajaGrafindo Persada

Yuvendri, R., \& Susanto, R. (2019). Meningkatkan Mutu Pelayanan Dalam Usaha Menghimpun Dana Masyarakat (Tabungan) Pada PT. Bank Perkreditan Rakyat Prima Mulia Anugrah Cabang Padang. https://doi.org/10.31219/osf.io/6prcd 